\title{
Research Article: Genetic divergence for crop improvement in short duration rice varieties as revealed by morphological traits
}

\section{RAJARAJAN AND S. THIRUMENI}

Article Chronicle: Received :

19.07.2017;

Accepted :

03.08.2017

KEY WoRds:

Genetic diversity, Short duration rice, Morphological traits
SUMMARY : A sustainable breeding programme could be achieved through precise knowledge of genetic divergence for yield components. Hybridization between diverse parents maximizes the chance of higher heterosis as it will give wide range of segregation which will promote chance of selection. It also helps to widen the genetic base of varieties in a breeding programme. With this in view this investigation was carried out with the objective of estimating genetic diversity present in a set of 29 short duration rice varieties recommended for cultivation in Tamil Nadu and Puducherry (U.T.), using morphological traits. Clustering based on average taxonomic distance using morphological traits grouped 29 varieties into two major clusters with 25 and 4 varieties respectively and produced distant genetic pools. The genetic diversity of the 29 short duration rice varieties was observed to be narrow and, therefore, it is necessary to broaden the genetic base of the present day rice cultivars by bringing in genes from large germplasm comprising land races and wild spp.

How to cite this article : Rajarajan, D. and Thirumeni, S. (2017). Genetic divergence for crop improvement in short duration rice varieties as revealed by morphological traits. Agric. Update, 12(TECHSEAR-7) : 1812-1816; DOI: 10.15740/HAS/AU/12.TECHSEAR(7)2017/1812-1816.
Author for correspondence :

\section{RAJARAJAN}

Pandit Jawaharlal Nehru College of Agriculture and Research Institute, Karaikal, PUDUCHERRY (U.T.) INDIA

See end of the article for authors' affiliations 